\title{
The information technology industrial revolution and its role in building business strategy of global retail
}

\author{
Lena Ellitan \\ Faculty of Business, Widya Mandala Catholic University Surabaya \\ Jalan Dinoyo 42-44. Surabaya. 60265. Indonesia \\ lena@ukwms.ac.id
}

Submitted: Mar 14, 2020; Reviewed: Apr 8, 2020; Accepted: Apr 30, 2020

\begin{abstract}
The need to process the rate of information more and more quickly, forcing companies to continue on innovate in the field of information technology and devices. A large wave flow and information flow must be immediately processed and used by the company to be able to maintain and improve its business performance. This article will focus on the discussion of the success of the giant online retail companies and how information technology supports its success and existence. Information technology is also the reason why conventional retail is unable to compete with online retail or ecommerce. Information technology is a catalyst for complementary change, which triggers new innovations that complement each other in business processes, such as finding new ways to reach customers, and new ways to communicate with suppliers and consumers. In other words, information technology has helped build the business strategy of global retail players in developing their business strategies. Likewise what happens in the global retail industry, they will continuously evolve to follow developments in Industry 4.0 and Society 5.0. This 4.0-era global retail company is a pioneer that utilizes the industrial revolution and builds its own dynasty in new retail models introduced by the global retail industry.
\end{abstract}

Keywords: business strategy; giant online retail companies; industrial revolution 4.0; information technology; society 5.0

\begin{abstract}
Abstrak: Kebutuhan untuk memroses laju informasi semakin cepat, memaksa perusahaan untuk terus berinovasi di bidang teknologi dan perangkat informasi. Aliran gelombang besar dan aliran informasi harus segera diproses dan digunakan oleh perusahaan untuk dapat memertahankan dan meningkatkan kinerja bisnisnya. Artikel ini akan berfokus pada diskusi tentang kesuksesan perusahaan ritel daring raksasa dan bagaimana teknologi informasi mendukung keberhasilan dan keberadaannya. Teknologi informasi juga menjadi alasan mengapa ritel konvensional tidak dapat bersaing dengan ritel online atau e-commerce. Teknologi informasi adalah katalis untuk perubahan komplementer, yang memicu inovasi baru yang saling melengkapi dalam proses bisnis, seperti menemukan cara baru untuk menjangkau pelanggan, serta cara baru untuk berkomunikasi dengan pemasok dan konsumen. Dengan perkataan lain, teknologi informasi telah membantu membangun strategi bisnis pemain ritel global dalam membangun strategi bisnisnya. Demikian juga apa yang terjadi di industri ritel global, mereka akan terus berkembang mengikuti perkembangan di Industry 4.0 dan Society 5.0. Perusahaan ritel global era 4.0 ini adalah pelopor yang memanfaatkan revolusi industri dan membangun dinastinya sendiri dalam model ritel baru yang diperkenalkan oleh industri ritel global.
\end{abstract}

Kata kunci: masyarakat 5.0; perusahaan ritel daring raksasa; revolusi industri 4.0; strategi bisnis; teknologi informasi 


\section{INTRODUCTION}

The need to process the rate of information more and more quickly, forcing companies to continue on innovate in the field of information technology and devices. A large wave flow and information flow must be immediately processed and used by the company to be able to maintain and improve its business performance. The Industrial Revolution 4.0 that occurred was accompanied by the very rapid development of information technology (IT), including in the development of retail companies both small and medium scale up to a global scale (Nagy, Oláh, Erdei, Máté, \& Popp, 2018). This paper will focus on discussing the success of the giant global retail and how IT supports its success and existence. The Retail Giant is a business model that has also evolved and developed following the Industrial Revolution 4.0 and the development of IT is also a reason why conventional retail is unable to compete with online retail or e-commerce. This is caused by technological developments that have also brought about changes in people's habits, so that the revolution of the business model in the Industrial Era 4.0 is important to be further studied (Muljani \& Ellitan, 2019).

Information technology is a catalyst for complementary change, which triggers new innovations that complement each other in business processes, such as finding new ways to reach customers, and new ways to communicate with suppliers and consumers. This change has a long-term effect on the ability of the company itself to create goods and services. For example, this can be seen in the early establishment of the Amazon company. Amazon initially started the wheel of its business by only selling books online but now it touches on everything from DVDs, clothing, to web hosting CDN (Content Delivery Networks). From this description, it can be said that to be at this stage, amazon has followed IT developments, made use of IT and made innovations in the IT field itself, and used IT as a support for developing business processes. Furthermore, not only Amazon, but in general the Industrial Revolution 4.0, which is happening now, has a lot to play in building a global e-commerce business.

\section{RESULTS AND DISCUSSION}

\subsection{Business model revolution in the industrial era 4.0}

The business model revolution in Industrial Era 4.0 gave many surprises and fast services to consumers. Often times, consumers are made curious by a phenomenon where the source of company income is when providing services without paying, or free, or even providing services by offering subsidies so that the services provided are much cheaper than those provided by the market. That is what companies who dominated in the Industrial Revolution 4.0 era did as Google, Facebook, Uber, Airbnb, etc. (Natalia \& Ellitan, 2019).

These companies managed to win the hearts of consumers so that they unconsciously got entangled using the services provided, and also the users had become commodities that could be resold to other commercial companies, traffic of service users who have gone through the production process into commodities to generate income indirectly. What's more this is supported by the implementation of Financial Technology known as FinTech (Koesworo, Muljani, \& Ellitan, 2019).

In the Industrial Revolution 4.0 there are a number of things that can make a successful business model (Morrar, Arman, \& Mousa, 2017). First, the company offers solutions to the problems faced by most people. Second, endless innovation. Third, the monopolistic model of new capitalism. Fourth, the Marketing Model 3.0 is a marketing model that sees customers not only as users of products but sees consumers from their multi-dimensions as human beings so that consumers will choose products that satisfy their desires to participate, create, community, and their idealism. Companies in this era tend to look for problems to be solved which also then take advantage indirectly (soft selling), are the characteristics of marketing in this era. Innovation seems to be the key word in competing in this era because innovation can answer problems and innovation is also needed in creating business models that can provide added value to the company.

In this era, commercial companies that are able to have a positive impact on human benefit will become large and the greater the positive impact that is given, the bigger the company will be. The 
aspects discussed above can be seen clearly in companies that implement e-commerce that is now emerging. Likewise what happens in the global retail industry, they will continuously evolve to follow developments in Industry 4.0 and Society 5.0. This 4.0-era global retail company was a pioneer who took advantage of the industrial revolution and built his own dynasty in the new retail model they introduced. Furthermore, it can be clearly seen that e-commerce companies utilize IT in revolutionizing the world retail industry (Yeming, 2018).

\subsection{Business strategy and the strategic orientation}

Business strategy is the direction of how a company runs its activities. The dynamics of a dynamic business environment with changes and increasingly fierce competition, it is not possible for organizations to take a traditional approach. Building a corporate culture and uncomplicated rules and strategic directions for all members of the organization is more effective than directing individual behavior through formal planning processes and hierarchical procedures (Puspita, Christiananta, \& Ellitan, 2020).

Some business strategy concepts are developed with different perspectives and approaches and their relationship to company performance. Strategy is an important part in strategic management to see the company's internal and external environment that is able to build competitive advantage that affects company performance. According to Huff, Floyd, Sherman, \& Terjesen (2009), strategy is to define and communicate what is created in the organization, by whom, how, to whom and why it is valuable. While performance is a factor that is above management control, organizational strategy is the main tool trusted by managers that can influence the performance of the company they manage.

Porter (1981) sees the company's performance is dependent on the choice of the industry they enter, different industries have different levels of performance. This idea sees that corporate-level strategy is related to the business portfolio that the organization enters. Strategies at the functional level are related to how to maximize the productivity of resources in specific functions. The strategy applied between corporate strategy and functional strategy, that is strategy at the business level (strategic orientation) related to how companies can compete effectively in each product and market chosen. Porter (1981) classifies strategies that are generic strategies at the business level on the axis: cost efficiency and product differentiation, which can also be seen as an alternative to the conceptualization of strategic orientation.

According to Tutar, Nart, \& Bingol (2015), strategic orientation is a tool for assessing and measuring key dimensions at the business level, which focuses on general strategic process behavior and some of the dimensions are related to the concept of entrepreneurial orientation (entrepreneurial vs conservative strategic posture). Tutar et al.'s (2015) contribution to strategic orientation has been received and has more meaning than its initial construct. Strategic orientation is usually used as a generic, umbrella that explains the differences in various constructs namely the market orientation, entrepreneurial orientation, learning orientation, and technological orientation. Each orientation suggests different adaptation mechanisms and different responses to the question how companies must compete in the selected product and market segments.

Hakala (2010) sees strategic orientation as a combination of a company's value position in its market, its resources and behavioral patterns related to how an organization converts resources into products and services that are of value to its target market. Strategic orientation must be seen and considered as a configuration of multiple dimensions. Hakala (2010) configuring the strategy orientation into four elements. First is market and customer orientation. Market orientation is seen as a culture or organizational activity that effectively creates the behavior needed to achieve superior performance. Second is technology orientation. Technology orientation is close to and related to innovation and product orientation terminology, referring to the company's interest in the introduction and use of new technologies, products or innovations with RBV strategic ideas, and technological resources, when combined uniquely will form competitive advantage. Third is entrepreneurial orientation. Entrepreneurial orientation is a strategic orientation that specifically describes aspects of entrepreneurial strategy within the company. Entrepreneurial orientation companies are companies whose top managers have an entrepreneurial management style, which is reflected in the company's strategic and operational 
decision making. The fourth is learning orientation. Learning is seen as developing and gaining new knowledge that has the potential to influence behavior. Learning orientation, corresponds to the definition of learning, described as an organization's tendency to create and use knowledge and processes to do so in an effort to gain competitive advantage. Finally, relationship orientation. Relational orientation, or also referred to as relational orientation, is defined in several points of view. Ho (2014) defines a broader relationship orientation not only with the customer, but also with other parts such as suppliers, government agencies, and stakeholders. This theory is used as the basis for discussing examples of global retail business success.

\subsection{Discussion of e-business strategies in global online retail companies}

Global retailing is the process of marketing and selling products to end consumers with global (international) consumer coverage. Prachi (2019) define global retailing as the concept of selling products across the geographical boundaries of a country to the consumers and all are available in the different parts of the world to attain global presence and recognition and to capture the opportunities prevailing in the potential overseas markets. In running global retail, there are several companies that can be studied and considered for their e-business concept, not only Amazon, but many other companies younger than Amazon, such as Tokopedia, Lazada, and other e-commerce companies began to emerge and participated in achieving success in this realm. Its success even has an impact on conventional retailing so that the question may arise, why Amazon, Tokopedia, and Lazada can get success, the main reason is that they are able to empower IT in line with the Industrial Revolution 4.0.

\subsubsection{Amazon and its various business strategies}

Amazon.com is a large online company that makes the most of this situation. Amazon.com has made various efforts to provide the best service and reasonable prices. Amazon is one of the most successful companies in existence; the Amazon business concept is very popular and has been popular since the very beginning of the Amazon's peak. Amazon again proved itself to be the strongest online retail company in the world today, even when the world was experiencing an economic slowdown. Amazon posted strong fourth quarter results in 2018, even though other retailers were struggling to slow down the pace of weakening sales. In the following section, this article will describe the strategies adopted by Amazon in running its company, among others (Hakim, 2018).

First are the discount strategy, diversification, and Amazon prime. The main driver that drives Amazon's revenue growth is competitive pricing policies. Amazon is intensifying its discount strategy to attract buyers. Apparently this works, because according to ComScore Amazon's traffic climbed 9.8\% compared to the previous year, compared to eBay's traffic which actually dropped $2.5 \%$. Amazon's revenue jumped $18 \%$ to as low as $\$ 6.7$ billion, while Amazon's net profit rose $9 \%$ to reach 52 cents per share, exceeding analyst expectations of 39 cents per share. Amazon's diversification beyond the initial product line also plays an important role. The Amazon product line was originally only books, music and films, but now it also covers electronics to other general merchandise. Electronics and merchandise sales in the fourth quarter jumped 31\%; meanwhile sales of media (books, music, and films) only grew by $9 \%$. In addition, the strategy that plays a major role in Amazon's strong quarterly results is the Amazon Prime program, a membership program where members only need to pay $\$ 79$ a year, with benefits including free shipping. Surely for these customers is a lucrative offer, because in a year they no longer need to pay shipping costs.

Second is customer relationship management (CRM). CRM is one means to establish an ongoing relationship between the company and its stakeholders and shareholders. By utilizing CRM, the company will know what is expected and needed by its customers, so that it will create an emotional bond that is able to create close and open business relationships and two-way communication between them (Ellitan \& Anatan, 2007). Thus, customer loyalty can be maintained and not easily move to other products and brands. Today, many companies are using various means in their efforts to improve CRM. In particular, the company tries to provide personalized services so that it can provide high satisfaction 
to its customers, both as stakeholders and shareholders. Thus, it is expected to establish a strong value chain between them through relationships with customers (Anatan \& Ellitan, 2018).

To implement a CRM strategy, it requires at least 3 (three) key factors, namely: professional people (adequate qualifications), well-designed processes, and adequate technology (leading-edge technology). Professionals not only understand how to deal with customers, but also understand how to use technology (for CRM). Anything without a good design will fail, so will CRM. The CRM user company must already know the business objectives and business requirements desired from the CRM implementation.

Amazon also has the infrastructure for CRM. Amazon's CRM infrastructure is as follows (Hakim, 2018). First, integrated customer data. The ability to access, process, and process everything related to customers is one of the keys to CRM success. Without clear data and information about customers, it will be difficult to know the wants and needs of customers. A good relationship with customers is to serve wherever they are, at any time, and by any means. An example is giving a waiter 24 hours. Second, integrated business processes. The business environment must be integrated, for example if sales and service are separate. Sales during the sales and service cycle after sales activity, but customers will get different answers depending on who they are talking to. Customers need service both at the time of purchase and afterwards. Third, integrated extended enterprise. To get customer loyalty for a product, a company must work closely with its partners, with CRM infrastructure vendors through the internet and intranet. With this infrastructure, companies and partners can share information, educate, and collaborate using web applications.

\subsubsection{Alibaba and its business strategy}

Alibaba's business concept, according to Yeming (2018) is to start from an e-commerce business and make the business a lifestyle. Alibaba carries a new retail concept that is expected to make life easier, so Alibaba has several products to realize this concept. There are several products owned by Alibaba are (Ariyanti, 2018).

First is Alibaba.com. Alibaba.com is an e-commerce company founded by Jack Ma and his colleagues in 1999. Alibaba has become one of the world's largest e-commerce giants. The number of buyers on the Alibaba.com site is claimed to have reached 190 countries. Its users are not only individuals, but also retailers, producers, large traders, and Small and Medium Enterprises (SMEs) engaged in the import-export business, as well as trade agents. Second is 1688.com. This product was born because Alibaba doesn't just want to dwell on Alibaba.com. Furthermore, Alibaba presents the 1688.com site, a local buying and selling site for retail and wholesale items. So it's like a wholesale market but via online. The items sold range from accessories, clothing, household furniture, to local beverage and food products. Usually, retail wholesalers in China get supplies from these sites.

The third Alibaba product is Taobao. Taobao is an e-commerce site or marketplace that is almost similar to e-Bay. Taobao was founded in 2003. Since June 2011, Jack Ma said that he will divide Taobao into three different companies, namely eTao, Taobao Mall, and Taobao Marketplace. In the customer service process, Taobao has a shopping agent service to facilitate customers from foreign or outside China to use their services. The popularity of smart phones is used by Alibaba to glance at e-commerce businesses that are friendly to mobile users.

The fourth product is Alimama. After four years after the release of Taobao, Alibaba resumed business expansion. In 2007, Alibaba established a company in the field of marketing technology named Alimama. Alimama provides a platform that responds to traders' needs, where traders can place marketing displays on third-party websites and applications. Thus, the range of promotions and marketing of traders who are members of Alimama will be wider.

The next Alibaba product is Tmall. In 2008, Alibaba developed a business to consumer (B2C) platform called TMall. The target is the upper class because this platform offers premium services. TMall's presence has attracted foreign brands to use the platform. Sixth is Alibaba Cloud, Alibaba Cloud is a company made by Alibaba established in 2009. The company plays in the business of cloud computing services that can be used by business people in China and other countries in the world, be it SMEs, large companies, startups, or government agencies. 
Alibaba continues to develop the seventh product, Ali Express. After a decade, Alibaba continued to expand by establishing a logistics or freight forwarding company in 2010 called Ali Express. With this service, buyers from other countries can buy products directly through large traders in China. Eighth is Cainiao Network. The logistics network company presented by Alibaba is Cainiao Network. There is one vision to be achieved, namely to send orders to consumers within 24 hours in the territory of China and only takes 72 hours to other countries. The next Alibaba product is Ant Financial. Alibaba Group also wants to try their luck by establishing fintech, Ant Financial in 2014. Now, Ant Financial is a global fintech giant from China through the Alipay application. Ant Financial offers secure financial inclusion services for small businesses and builds a joint credit system. Ant Financial, on November $1^{\text {st }}, 2016$, officially injected funds into the Ascend Money Company which is the parent company of the e-money service True Money. True Money has been in Indonesia since September 2015, after acquiring an emoney licensee in Indonesia, Witami Cash Mandiri.

In 2016, Alibaba founded Alibaba Pictures. This shows the expansion continues to expand, Alibaba Group plays in the film and entertainment business by establishing Alibaba Pictures. The company immediately bought a minority share of DreamWorks Pictures owners. In addition, it reached hundreds of millions of US dollars to buy shares of the Chinese cinema company Wanda Film and invest in two well-known films. Last time, Alibaba had Youku. Youku is one of the most popular video streaming sites in China. Thanks to Youku's presence, Alibaba's revenue from this sector jumped more than 40 percent every year.

\subsubsection{Tokopedia and competitive strategies in the industrial age 4.0}

Tokopedia (www.tokopedia.com) comes as an innovative new e-commerce that carries the concept of a collection of various online stores in Indonesia. All trading activities and transaction processing will be guaranteed security through the mediation of Tokopedia. This concept is expected to be able to realize an online mall form that initiates and coordinates a number of e-commerce transactions (Marixon, 2019). The advantage given by Tokopedia is that being a seller in Tokopedia is not difficult. Opening an online store can be done for free. In addition, there are a number of facilities and features that support the ease of doing business that can be obtained by the seller. In addition, to facilities such as store management, product classification, and transaction processing, sellers will also get sub domains to facilitate access to the seller's online store.

The product marketing process at Tokopedia can be done by displaying products on a shop window using the Showcase feature. Thus, the opportunity to get new customers is even greater. the seller will also be given the facility to calculate shipping costs and tracking orders easily without having to access directly to the website that provides package delivery services. This can be done because Tokopedia has cooperated with some of the largest delivery service companies in Indonesia. Just enter the product size information and the destination area and then Tokopedia immediately helps the process of calculating shipping costs quickly and accurately.

The payment transaction process will also take place securely through Tokopedia's official escrow account. The Tokopedia team will send the payment amount to the seller after receiving confirmation of receipt of the goods from the buyer. Further guidance on the process can be found on the Tokopedia website. While for customers who want to buy products on Tokopedia, all they need to do is type the product name in the search field or browse through each product category on the Tokopedia website. Through the Tokopedia communication feature called "Talk About It", customers can also interact communicatively to talk about the product they want to buy.

After explaining the various strategies of the three examples of retail execution, there are a number of things that need to be underlined. Alibaba can be one of the biggest companies in China because they have several successful business strategies (Yeming, 2018). First, global business expansion of Alibaba companies do business globally to various countries to market their products. For example, Lazada which is marketed to Southeast Asian countries such as Indonesia, Malaysia, Thailand, etc. In this case, Alibaba wants to continue to expand to develop its business. Second, customer focus, Alibaba here always has a main focus in this matter to its customers. Here Alibaba wants to always prioritize customer satisfaction. Customer satisfaction and trust can make customers survive and always feel comfortable using Alibaba products. Third, investment in several companies. As a large company, Alibaba does not 
forget to invest to grow. Here Alibaba makes investments in several companies such as Amazon, Tokopedia, Lazada, etc. Here Alibaba wants to get favorable feedback from the companies they invest because they believe that the companies they invest will develop and produce large profits.

\section{CONCLUSION}

In the development of global retail, companies engaged in e-commerce are gradually becoming huge giants in their fields. All of this was preceded by the development of IT in the Industrial Revolution 4.0. This later revolution gave birth to the concept of e-commerce business, which is a new retail concept. This new retail concept offers a lot of convenience for its consumers, which can be said to be the main attraction of almost all existing e-commerce companies. Nowadays, the retail giant is not only selling convenience and security in transactions, but also offers convenience in living everyday life. This can be seen from e-commerce products outside the marketplace services, for example like Alipay and so on. This can be observed as an interesting phenomenon where the retail giant is not only focused on selling goods, but also selling services that serve to facilitate those services which build giants global retail.

With the advancement of increasingly sophisticated technology will make it easier for all parties such as industry, companies, consumers, and society in general in all respects. This transformation will help humans to live more meaningful lives. Innovation in Industry 4.0 and Society 5.0 will reach a forward-looking society that breaks the existing stagnation and the dynamics of business and society will be even higher.

From the discussion of this paper, in the future, there will be no leeway and retail businesses, especially those on a global scale because change will be faster. This paper is expected to make a practical contribution after seeing the existence of new trends and several medium and long term trends. The retail business will be able to survive when these business people begin to apply more intensive customer relations. Customer service will become the root of the retail business reaching a new level of maturity. The elements of the global retail model will be highly digital will permeate all existing retail business models. Technologies, such as $5 \mathrm{G}$, will allow retailers to move faster and operate more streamlined. Global and local retail businesses will continue to grow to become increasingly important and have an impact on companies and consumers. For local retail businesses, this is a challenge to be more courageous to do disruptive innovation.

\section{REFERENCES}

Anatan, L. \& Ellitan L. (2018). Suppy chain managemet: teori dan aplikasi. Edisi 2. Bandung: Alfabeta

Ariyanti, F. (2018, 13 November). Mengenal Alibaba Grup, kerajaan bisnis milik Jack Ma dari China. Diperoleh dari https://www.cermati.com/artikel/mengenal-alibaba-grup-kerajaan-bisnis-milikjack-ma-dari-china

Ellitan, L. \& Anatan, L. (2007). Strategi bersaing dalam service driven economy. Yogyakarta: Andi Offset

Hakala, H. (2010). Strategic orientations in management literature: Three approaches to understanding the interaction between market, technology, entrepreneurial, and learning orientation. International Journal of Management Reviews, 13(2), 199-217.

Hakim, L. (2018, 10 April). Konsep e-business pada perusahaan Amazon.com. Diperoleh dari http://student.blog.dinus.ac.id/ludfihakim96/2018/04/10/konsep-e-business-pada-perusahaanamazon-com/

Ho, Y.W. (2014). Multiple strategic orientation and business performance: a comphrehensive investigation of high-tech firms. Diperoleh dari https://digital.library.adelaide.edu.au

Huff, A.S., Floyd, S.W., Sherman, H.D., \& Terjesen, S. (2009). Strategic management: Logic and action. John Willey and Sons

Koesworo, Y., Muljani, N., \& Ellitan, L. (2018). Fintech in the industrial revolution era 4.0. International Journal of Research Culture Society, 3(9), 3-9.

Marikxon. (2019, 8 September). Tokopedia - ecommerce lokal berkonsep mall online. Diperoleh dari https://www.maxmanroe.com/tokopedia-ecommerce-lokal-berkonsep-mall-online.html

Morrar, R., Arman, H., \& Mousa, S. (2017). The fourth industrial revolution (industry 4.0): A social innovation perspective. Technology Innovation Management Review, 7(11), 12-20 
Muljani, N. \& Ellitan, L. (2019). Developing competitiveness in industrial revolution 4.0. International Journal of Trend in Research and Development, 6(5), 1-3

Nagy, J., Oláh, J., Erdei, E., Máté, D., \& Popp, J. (2018). The role and impact of industry 4.0 and the internet of things on the business strategy of the value chain-the case of Hungary. Sustainability, 10, 1-25. Diperoleh dari www.mdpi.com/journal/sustainability

Natalia, I. \& Ellitan, L. (2019). Srategies to achieve competitive advantage in industrial revolution 4.0. International Journal of Research Culture Society, 3(6), 10-16

Porter, M.E. (1981). The contribution of industrial organization to strategic management. The Academy of Management Review, 6(4), 609-620

Prachi. M. (2019). Global retailing. Diperoleh dari https://theinvestorsbook.com/global-retailing.html

Puspita, L.E., Christiananta, B., \& Ellitan, L. (2020). The effect of strategic orientation, supply chain capability, innovation capability, on competitive advantage, and performance of furniture retails. International Journal of Scientific \& Technology Research, 9(03), 4521-4529

Tutar, H., Nart, S., \& Bingol, D. (2015). The effect of strategic orientation on innovation capabilities and market performance: The case of ASEM. Procedia Social Behavioral Sciences, 207, 709-719

Yeming, W. (2018, 15 Agustus). Konsep ritel baru untuk dunia dari Alibaba. Diperoleh dari https://teknologi.bisnis.com/read/20180816/105/828890/konsep-ritel-baru-untuk- dunia-darialibaba 